\title{
Study on the GTAP Simulation Trade Development between China and Pakistan
}

\author{
Ying Shou
}

No 99 Shangda Road, Baoshan District, Shanghai, China

290471008@qq.com

\author{
Keywords: The Belt and Road; Pakistan; GTAP Model
}

\begin{abstract}
The Belt and Road" strategy is a major innovation to strengthen international cooperation between China and Asia, Europe and Africa. This article focuses on the impact of tariff cuts between China and Pakistan on the trade between the two countries in the context of "the Belt and Road". The GTAP model is used to conduct a comparatively static general equilibrium simulation analysis of the impact of tariff reductions on the GDP, social welfare, and import and export levels of the two countries and the world from the perspective of empirical analysis.

The empirical results show that the reduction of tariffs on trade in goods between China and Pakistan will have an impact on both sides and the world and will have a positive effect on China's and Pakistan's total GDP and social welfare. And the greater the tariff reduction, the greater the welfare of China and Pakistan and the welfare of the rest of the world. From the perspective of import and export, China's exports have increased, and imports have decreased. With the advancement of "the Belt and Road" strategy, the reduction of tariffs between China and Pakistan will further expand the trade balance between the two countries. Second, different products are sensitive to tariff cuts at varying degrees. Among them, China's textile and apparel imports are affected more seriously. Finally, China's crop production, aquaculture, extractive industries, and processed food industries have been hit by tariff cuts, output has declined, while output from the textile and garment industry, light industry, heavy industry, and infrastructure has increased.
\end{abstract}

\section{Introduction}

From May 14th to 15th, 2017, the "The Belt and Road" International Cooperation Summit was successfully held in Beijing. This is an international event for all parties involved to jointly build "the Belt and Road" and share the fruits of mutually beneficial cooperation. At the same time, this is also an important platform for cooperation in strengthening international exchanges and cooperation and connecting development strategies of various countries. China and Pakistan have maintained good diplomatic relations since the founding of New China. Since the reform and opening up, China-Pakistan relations have developed rapidly. Especially since the establishment of the ChinaPakistan Free Trade Area and the construction of the "China-Pakistan Economic Corridor", the two countries have carried out all-round cooperation in the fields of economic and trade development, foreign direct investment, energy cooperation and infrastructure construction. Since the implementation of the "the Belt and Road" strategy, Pakistan has become an important strategic partner of China. What is the impact of tariff cuts between China and Pakistan on the trade between the two countries after the "belt and road" is the main research purpose of this paper.

\section{Literature Review}

One of the goals of the "The Belt and Road" strategy is to promote the free flow of economic factors, the efficient allocation of resources and the deep integration of markets, thereby promoting the coordination of economic policies among countries along the line to carry out regional cooperation on a larger scale, deeper level and higher level. Zhang Guihong (2011) explored the relationship between the two countries from the perspective of Pakistan's geographical advantages. He believes that although there are many problems in the relationship between China and Pakistan, due to Pakistan's unique geographical advantages, it has important strategic significance for China. Pakistan is the key to China's westward departure from the Indian Ocean and break hrough the difficult situation in the Straits of Malacca. Liang Tong (2016) analyzed the homogeneity of the "New Silk Road" plan proposed by the United States and the "the Belt and Road" strategy of China and analyzed the geographical impact of the China-Brazil Economic Corridor on the US "New Silk Road" plan. He believes that China's interconnection and intercommunication initiative proposed in the "the Belt and Road" strategy will make China the dominant commodity circulation on the Eurasian continent, thus weakening the geopolitical position of the United States. This will cause concern in the United States, causing the United States to interfere and contain the construction of the China-Pakistan Economic Corridor from both Pakistan and the region. From the 
perspective of quantitative analysis, Gao Zhigang and Zhang Yan (2015) used the stochastic frontal gravitational model to analyze the trade potential and efficiency of China-Pakistan economic corridor construction. They believe that the potential of bilateral trade between China and Pakistan is far greater than the trade potential of China's exports to Pakistan. Therefore, China should seize the opportunity of the construction of the ChinaPakistan Economic Corridor and the Belt and Road construction, fully tap the trade potential of both sides, and improve trade channels, trade environment and institutional arrangements.

\section{Current Development of Trade between China and Pakistan}

China and Pakistan have achieved many achievements in infrastructure, trade and energy cooperation. From the perspective of trade, in November 2006, China and Pakistan signed the "5-Year Development Plan for ChinaPakistan Economic and Trade Cooperation" and signed the "China-Pakistan Free Trade Area Agreement", which became effective on October 10, 2009. In 2013, the "China-Pakistan Economic Corridor" was proposed. With the advancement of the "the Belt and Road" strategy, China and Pakistan have further developed trade cooperation between the two countries and promoted trade liberalization between the two countries. From May 14th to 15th, 2017, at "The Belt and Road" International Cooperation Summit held in Beijing, Pakistan and China signed "the Belt and Road" cooperation document in the field of transportation. And China and Pakistan signed documents such as infrastructure financing cooperation agreements and economic and trade cooperation agreements in ports, power and industrial parks. Pakistan has achieved many achievements with China and has contributed to the creation of an efficient and convenient international trading environment.

\section{Empirical Analysis based on GTAP}

Model Introduction and Classification Method. The Global Trade Analysis Project (GTAP) is a general equilibrium model developed by Purdue University in the United States. It is widely used to study trade policies for multinational (multi-regional), multi-sectoral real GDP, welfare levels, output, Import and export and other influences. This paper uses the ninth edition of the GTAP model, covering 140 countries (regions), 57 industries, and 8 production factors in the world, providing a great degree of freedom for analyzing trade.

Technical Route and Program Settings. Since China proposed the important cooperation initiative for the construction of the Silk Road Economic Belt and the 21st Century Maritime Silk Road in 2013, the construction of "the Belt and Road" has progressed smoothly and has achieved fruitful results and has been widely welcomed and highly praised by the international community. During the summit and on the eve of the summit, governments, localities and enterprises reached a series of cooperation consensus, important measures and pragmatic results. As can be seen from the previous results and results list, one of the important purposes of the "the Belt and Road" construction is to promote the smooth flow of trade along the countries, that is, to continuously reduce tariff and non-tariff barriers between countries along the route. Since the statistical system of trade in services has not yet been perfected, this paper mainly analyzes the impact of tariff cuts between China and Pakistan on trade in goods.

In simulating the impact of tariff cuts on trade between China and Pakistan, it is assumed that: (1) tariffs are used as shock variables and other non-tariff barriers are not considered. (2) The tariffs are gradually phased out between China and Pakistan, and the tariffs with other countries remain unchanged. (3) Do not change the basic assumptions in the GTAP model.

The specific scheme of this paper is set as follows:

Scheme 1 (S1): With the Belt and Road, tariffs on China and Pakistan are cut by $50 \%$.

Scheme 2 (S2): With the Belt and Road, China and Pakistan have zero tariffs, which means free trade.

Simulation Results and Analysis.

1) Changes in GDP and welfare of countries (regions)

Table 4 shows that under both schemes, tariff cuts between China and Pakistan will increase both GDP and welfare. In the case of Scheme S1, the tariff between China and Pakistan was reduced by $50 \%$, the GDP of both parties increased by $0.022 \%$ and $0.356 \%$, respectively, and the benefits increased by US $\$ 262.705$ million and US\$105.812, respectively. The GDP of Pakistan and China has increased significantly, and both countries have benefited from tariff cuts.

The GDP and welfare of other countries in non-tariff reduction countries have been negatively affected to varying degrees. Among them, India and the United States were affected more, India's welfare decreased by 15.957 million US dollars, and US welfare decreased by 12.762 million US dollars. This may be caused by two reasons. First, the trade volume between the United States and India is inherently large, so the absolute value of the impact is relatively large. Second, the relationship between India and the United States and Pakistan is closer than other countries. 
Table 4 Comparison of GDP and EV of each country in the case of S1 and S2

\begin{tabular}{|c|c|c|c|c|}
\hline & \multicolumn{2}{|c|}{$\mathrm{S} 1$} & \multicolumn{2}{|c|}{$\mathrm{S} 2$} \\
\hline & $\begin{array}{l}\text { GDP } \\
(\%)\end{array}$ & $\begin{array}{c}\text { EV } \\
\text { (One million } \\
\text { U.S. dollars) }\end{array}$ & $\begin{array}{l}\text { GDP } \\
(\%)\end{array}$ & $\begin{array}{c}\text { EV } \\
\text { (One million } \\
\text { U.S. dollars) }\end{array}$ \\
\hline China & 0.022 & 262.705 & 0.045 & 525.406 \\
\hline Pakistan & 0.356 & 105.812 & 0.714 & 211.621 \\
\hline India & -0.005 & -15.957 & -0.011 & -31.914 \\
\hline USA & -0.001 & -12.762 & -0.002 & -25.523 \\
\hline Kazakhstan & -0.002 & -9.071 & -0.001 & -18.142 \\
\hline $\begin{array}{c}\text { Other Central } \\
\text { Asian countries }\end{array}$ & -0.001 & -8.046 & -0.001 & -16.087 \\
\hline EU & -0.001 & 1.808 & -0.002 & 3.616 \\
\hline $\begin{array}{l}\text { Other countries } \\
\text { in the world }\end{array}$ & -0.002 & -35.601 & -0.003 & -71.200 \\
\hline
\end{tabular}

Source: RunGTAP simulation results

From S2, when the tariff cut between China and Pakistan is zero, the GDP and welfare levels of China and Pakistan will further increase, and the welfare of the rest of the world will be further impaired. Among them, the GDP of China and Pakistan will increase by $0.045 \%$ and $0.714 \%$ respectively, and the welfare will increase by 525.406 million US dollars and 211.621 million US dollars respectively.

From the above analysis, we can find that the reduction of tariffs between China and Pakistan will increase the welfare of the two countries, while the welfare of the rest of the world will suffer certain losses, but the overall welfare of the world will increase to some extent. And the greater the tariff reduction, the greater the welfare of China and Pakistan and the welfare of the rest of the world.

2) Changes in import and export of different countries

Table 5 shows the changes in the import and export situation of countries caused by tariff cuts between China and Pakistan. As can be seen from the table, in the case of Option S1, China and Pakistan's export changes were $0.016 \%$ and $0.314 \%$, respectively, and import changes were $-0.001 \%$ and $0.001 \%$, respectively. In the case of Scheme S2, the changes in imports and exports between China and Pakistan were even more pronounced. China's exports increased by $0.031 \%$, imports decreased by $0.003 \%$, Pakistan's exports decreased by $0.648 \%$, and imports increased by $0.002 \%$. China's exports have increased, imports have decreased, Pakistan's exports have decreased, and imports have increased. Although the proportion is not large, the conversion into trade volume is quite objective.

Table 5 Comparison of import and export situation of different countries in the case of S1 and S2

S1 S2

\begin{tabular}{ccccc} 
& $\begin{array}{c}\text { Export } \\
(\%)\end{array}$ & $\begin{array}{c}\text { Import } \\
(\%)\end{array}$ & $\begin{array}{c}\text { Export } \\
(\%)\end{array}$ & $\begin{array}{c}\text { Import } \\
(\%)\end{array}$ \\
\hline China & 0.016 & -0.001 & 0.031 & -0.003 \\
Pakistan & -0.314 & 0.001 & -0.648 & 0.002 \\
India & -0.004 & 0.001 & -0.008 & 0.001 \\
USA & -0.001 & 0.002 & -0.002 & 0.001 \\
Kazakhstan & -0.001 & 0.001 & -0.001 & 0.002 \\
$\begin{array}{c}\text { Other Central Asian } \\
\text { countries } \\
\text { EU }\end{array}$ & -9.621 & 0.001 & -0.001 & 0.002 \\
$\quad \begin{array}{l}\text { Other countries in the } \\
\text { world }\end{array}$ & -0.001 & -0.001 & -0.002 & -0.001 \\
\end{tabular}

Source: RunGTAP simulation results

3) Changes in import and export of major products 
Table 6 shows the impact of tariff cuts between China and Pakistan on the import and export of different sectors under the two scenarios of S1 and S2. The simulations show that different products are sensitive to tariff cuts. Among them, the impact of China's textile and apparel imports is relatively serious, $0.301 \%$ in the case of tariff reduction of $50 \%$, and $0.601 \%$ in the case of zero tariff reduction. As far as exports are concerned, China's aquaculture, extractive industries, and processed foods are negatively affected, and in the case of scenario S1, they are $-0.139 \%,-0.077 \%$, and $-0.043 \%$, respectively. In the case of scenario S2, it is $-0.279 \%, 0.153 \%$, and $0.086 \%$, respectively, while heavy industry and infrastructure are affected by a large positive impact. In the case of scheme $\mathrm{S} 1$, exports increased by $0.136 \%$ and $0.086 \%$, respectively, and in the case of scheme S2, exports increased by $0.273 \%$ and $0.172 \%$, respectively.

Table $6 \quad$ Comparison of China's import and export changes in the case of S1 and S2

\begin{tabular}{ccccc}
\hline & \multicolumn{2}{c}{ S1 } & & S2 \\
\cline { 2 - 5 } & Import & Export & Import & Export \\
\hline Planting & 0.057 & 0.055 & 0.113 & 0.120 \\
Aquaculture & 0.069 & -0.139 & 0.139 & -0.279 \\
Mining & 0.031 & -0.077 & 0.061 & -0.153 \\
Processed food & 0.054 & -0.043 & 0.109 & -0.086 \\
Textile and Apparel & 0.301 & 0.040 & 0.601 & 0.080 \\
Light industry & 0.069 & 0.029 & 0.138 & 0.059 \\
Heavy industry & 0.046 & 0.136 & 0.091 & 0.273 \\
Infrastructure & 0.047 & 0.086 & 0.093 & 0.172 \\
\hline
\end{tabular}

Source: RunGTAP simulation results

\section{Policy Suggestions}

The following analysis results suggest some countermeasures and suggestions for China's trade development with Pakistan during the construction of the Belt and Road.

First, accelerate the structural transformation of China-Pakistan trade. From the analysis of the current situation of trade and the simulation results of this paper, it can be seen that there is a complementary structure of trade structure between China and Pakistan, but it also shows problems such as the expansion of trade balance. This is mainly reflected in the large differences in the structure of goods exported between the two countries. For example, China mainly exports high-tech mechanical and electrical products to Pakistan, while Pakistan mainly exports labor-intensive textiles and clothing to China. The export products are relatively simple and low in technical content. This problem can be solved through trade cooperation between the two countries.

Second, strengthen Pakistan's development in infrastructure construction. The backward infrastructure construction in Pakistan is an important reason for restricting its development. Whether it is a rail transport route or a road transport route, Pakistan's transport routes are in the midst of bottlenecks that need to be upgraded. The smooth trade in "the Belt and Road" also requires China to build an international channel linking South Asia with China. Only by effectively connecting the regions and forming a regional transportation network can the transportation capacity between regions be expanded. China has proposed the establishment of an Asian infrastructure investment bank. The infrastructure construction project of the China-Pakistan Economic Corridor includes the development of the deep-sea port, Gwadar Port.

\section{References}

[1] Gao Xincai, Zhu Zegang, 2014: "The Silk Road Economic Belt Construction and China's Trade Response: Research Based on Gravity Model", Journal of Lanzhou University (Social Science Edition), Vol. 42, No. 6: P1 2; P4 6.

[2] Zhang Honggui, 2011: "The Strategic Position of Pakistan and the Future of China-Pakistan Relations", South Asian Studies Quarterly, No. 6: p14 17. 
[3] Liang Tong, 2016: "Analysis of the Geographical Impact of the China-Pakistan Economic Corridor on the US "New Silk Road" Project", South Asian Studies, No. 3: P20 37.

[4] Gao Zhigang, Zhang Yan, 2015: "Study on the Bilateral Trade Potential and Efficiency in the Construction of China-Pakistan Economic Corridor-Based on the Analysis of Stochastic Frontier Gravity Model, Journal of Finance and Economics, No. 11: P101 110.

[5] Lu Yanzhen, 2016: Research on the Relationship between China and Pakistan's Goods Trade, Master thesis of Yunnan University.

[6] Wan Lu, 2011: "Economic Effects of TPP Strategy in the United States-Analysis Based on GTAP Simulation", Contemporary Asia Pacific, No. 4: P22 27.

[7] Liu Yu, Zhang Yaxiong, 2011: "The Impact of EU-Korea Free Trade Zone on China's Economy and Trade_-Based on Dynamic GTAP Model", International Trade Issues No. 11: P106 115.

[8] Zhao Jinlong, Cheng Xuan, Gao Zhonghuan, 2013: "Study on the Potential Economic Impact of China-Japan-Korea FTA—Based on Dynamic Recursive CGE Model", International Trade Issues No. 2: P58 67.

[9] Liu Yu, Lu Yikang, Quan Shuiping, 2016: The Economic Impact of Trade Facilitation under the "The Belt and Road" Strategy_ A Study of the GTAP Model Based on the Sino-Kazakhstan Trade, Economic Review Phase 6 P70 83.

[10] Huang Xianhai, Chen Hangyu, 2016: "Research on the Implementation Effect of "The Belt and Road" - Simulation Analysis Based on GTAP”, Social Science Front, No. 5: P39 49. 